\title{
Pengembangan Modul Elektronik Menulis Teks Tanggapan Berbasis LMS Moodle dengan Muatan Ekoliterasi untuk Kelas 9
}

\author{
Responses Text Writing Module Development Based LMS Moodle Including Ecoliteracy \\ for $9^{\text {th }}$ Grade
}

\author{
Sella Auliya Rahmah ${ }^{1}$ dan Didin Widyartono ${ }^{2, *}$ \\ ${ }^{1,2}$ Fakultas Sastra Universitas Negeri Malang \\ ${ }^{1}$ Email: sellaauliarahma@gmail.com \\ ${ }^{2}$ Corresponding email: didin.fs@um.ac.id
}

Received: 28 June 2021 Accepted: 8 September 2021 Published: 5 November 2021

\begin{abstract}
This research purposed to produce a Moodle module based ecoliteracy for 9th grade. This study used five methods, (1) preliminary analysis, (2) product development, (3) expert validation and revision, (4) small-scale field trials and revision, and (5) large scale product trial. This research produces a Moodle module with ecoliteracy in its content and presentation which has been validated by material, media, and language expert with certain qualifications. This study result is suitable product that get validation score $87.5 \%$ for material, $92.5 \%$ for media, and $70.5 \%$ for language. The result from small field trials is $75 \%$, and $87.5 \%$ for large field trials, the product declared as suitable to use. This study ecoliteracy in the module content is contained in its themes, learning objectivities, materials, exercise, and cases that students must responses. Ecoliteracy in the module presentation is include in text, images, audios, and videos.
\end{abstract}

Keywords: electronics module, responses text writing, ecoliteracy

Abstrak: Penelitian ini dilakukan dengan tujuan menghasilkan modul elektronik berbasis ekoliterasi untuk kelas 9. Metode penelitian yang digunakan dalam penelitian ini terdiri atas lima tahap, yaitu (1) analisis kebutuhan, (2) pengembangan produk, (3) validasi ahli dan revisi, (4) uji coba lapangan skala kecil dan revisi, serta (5) uji coba produk skala besar. Penelitian ini menghasilkan modul elektronik dengan muatan ekoliterasi dalam isi konten dan penyajiannya yang telah divalidasi oleh ahli materi, media dan bahasa dengan kualifikasi tertentu. Penelitian ini menghasilkan produk layak guna dengan skor $87,5 \%$ untuk validasi materi, 92,5\% untuk validasi media, dan 70,5\% untuk validasi bahasa. Hasil uji coba lapangan diperoleh skor layak guna sebesar 85,7\%. Dengan demikian produk ini dinyatakan layak dikembangkan. Ekoliterasi dalam konten modul terdapat dalam tema, tujuan pembelajaran, materi, latihan, dan kasus yang harus ditanggapi oleh siswa. Ekoliterasi dalam sajian modul terdapat dalam teks, gambar, audio, dan video.

Kata kunci: modul elektronik, menulis teks tanggapan, ekoliterasi

To cite this article:

Rahmah, S. A., \& Widyartono, D. (2021). Pengembangan Modul Elektronik Menulis Teks Tanggapan Berbasis LMS Moodle dengan Muatan Ekoliterasi untuk Kelas 9. Diglosia: Jurnal Kajian Bahasa, Sastra, dan Pengajarannya, 4(4), 473-486. https://doi.org/10.30872/diglosia.v4i4.259 


\section{A. PENDAHULUAN}

Ekoliterasi adalah kemampuan memahami pentingnya penerapan prinsipprinsip ekologi untuk menciptakan masyarakat berkelanjutan yang muncul sebagai respons atas munculnya isu-isu lingkungan (Yuniawan, 2017). Isu-isu lingkungan tersebut di antaranya adalah masalah pemanasan global, penggerusan luas hutan, kerusakan lingkungan laut, dan masalah sampah yang datang dari berbagai faktor, termasuk manusia. Langkah-langkah inovatif dilakukan untuk mengatasi masalahmasalah lingkungan tersebut, di antaranya adalah mengintegrasikan pendidikan dengan wawasan lingkungan hidup dan ekoliterasi untuk membentuk pemikiran kritis siswa akan masalah lingkungan. Menurut Setyaningrum dan Gunansyah (2020) penanganan masalah lingkungan ini berhubungan dengan salah satu bentuk literasi, yaitu ekoliterasi atau literasi ekologi.

Ekoliterasi dipandang sebagai sebuah solusi untuk membentuk masyarakat berkelanjutan yang memiliki wawasan dan menerapkan perilaku yang sesuai dengan prinsip-prinsip ekologi (Long et al., 2014). Semetsky (2010) menyatakan bahwa integrasi ekoliterasi dalam bidang pendidikan dapat diterapkan melalui proses pembelajaran, pemilihan sumber ajar, dan media pembelajaran. Salah satu cara yang dilakukan melalui pemilihan media ajar adalah melalui pengembangan modul elektronik dalam platform Moodle yang mengintegrasikan ekoliterasi. Rigolon (2012) menyatakan bahwa penerapan ini diperlukan untuk mengasah keterampilan menulis siswa dan menumbuhkan sikap siswa yang proaktif terhadap pelestarian lingkungan.

Pengembangan modul elektronik berbasis ekoliterasi dilakukan untuk memuat materi dengan wawasan ekologis yang dekat dengan siswa, contohnya adalah terdapatnya materi yang kontekstual dan menjunjung kearifan lokal. Materi yang digunakan dalam pengembangan produk adalah materi menulis teks tanggapan dengan berbagai topik masalah ekologi beserta penanganannya yang dekat dengan siswa. Dengan demikian, siswa mampu mengasah keterampilan menulisnya, serta mengembangkan kemampuan berpikir kritisnya. Dengan menulis, siswa dapat menunjukkan caranya untuk turut aktif dalam pelestarian lingkungan dengan cara mengungkapkan gagasan kritisnya dalam bentuk tanggapan (Sulaiman, 2020).

Pemilihan LMS Moodle sebagai platform mengembangkan media pembelajaran modul elektronik karena fitur-fitur pendukung yang ada di dalamnya. Moodle dapat diakses secara elektronik dengan mudah dan aman. Moodle memiliki tampilan yang menarik dan dapat didesain secara interaktif untuk kemudahan belajar siswa. Konten dan tampilan dalam Moodle juga dapat secara mudah dimodifikasi sesuai kebutuhan pembelajaran. Terdapat fitur penyimpanan fail dalam Moodle sehingga fail modul berbentuk PDF juga dapat disimpan.

Penelitian yang pernah dilakukan berkenaan dengan pengembangan sebelumnya di antaranya adalah Pengembangan Bahan Ajar Menulis Teks Laporan Hasil Observasi Bertema Green Industry sebagai Pembentuk Scientific Awareness oleh Syukron (2018). Perbedaan penelitian ini dan penelitian sebelumnya terletak pada produk yang dikembangkan dan jenis materi yang dipilih. Penelitian sebelumnya Penelitian sebelumnya mengembangkan produk berupa bahan ajar, sedangkan penelitian ini mengembangkan modul elektronik. Teks yang dipilih pada penelitian sebelumnya adalah teks observasi, sementara penelitian ini menggunakan teks tanggapan.

Modul elektronik menulis teks tanggapan berbasis ekoliterasi dikembangkan berdasarkan kebutuhan yang ada di lapangan. Berdasarkan penelitian pendahuluan yang dilakukan, ketersediaan bahan ajar atau media pembelajaran Bahasa Indonesia 
berbentuk elektronik yang mengintegrasikan ekoliterasi belum mencukupi, padahal media pembelajaran ini sangat diperlukan seiring perkembangan teknologi dan kemudahan akses belajar (Wulandari et al., 2017). Kebutuhan ini juga dalam rangka penanganan masalah ekologi. Pembelajaran jarak jauh yang berlangsung selama era Covid-19 menuntut pengembangan perangkat yang dapat mencapai tujuan pembelajaran secara optimum (Banki, 2021). Hal ini juga berlaku untuk pengembangan media. Selain itu, media yang dikembangkan haruslah sesuai dengan tingkat perkembangan intelektual siswa.

Tujuan pembelajaran yang harus dicapai bukan sekadar pada ketercapaian perkembangan kognitif, namun juga afektif (Artani, 2020). (Mairina et al., 2021) menyatakan bahwa tujuan tersebut tidak dapat dicapai apabila pembelajaran hanya mengakomodasikan tugas-tugas saja dengan alasan keterbatasan, namun harus diusahakan cara membuat pembelajaran menarik dengan tetap mempertimbangkan kemudahan akses oleh siswa. Pengembangan media pembelajaran yang mengintegrasikan kemampuan kognitif dan afektif berbasis teknologi serta dapat diakses secara daring melalui Moodle dan diakses secara luring dalam bentuk PDF ini menjadi solusi yang dipilih untuk memecahkan masalah yang ada. Hal ini karena dengan bentuk modul elektronik, tujuan pembelajaran dapat dicapai dengan cara yang lebih efektif serta memudahkan siswa selama pembelajaran jarak jauh.

\section{B. METODE}

Penelitian ini menggunakan model penelitian Borg \& Gall yang telah diadaptasi, melalui lima tahap utama yaitu, penelitian pendahuluan berupa melakukan analisis produk yang akan dikembangkan dan perencanaan, mengembangkan produk awal, validasi ahli dan revisi, uji coba lapangan skala kecil dan revisi, dan uji coba lapangan skala besar dan produk akhir.

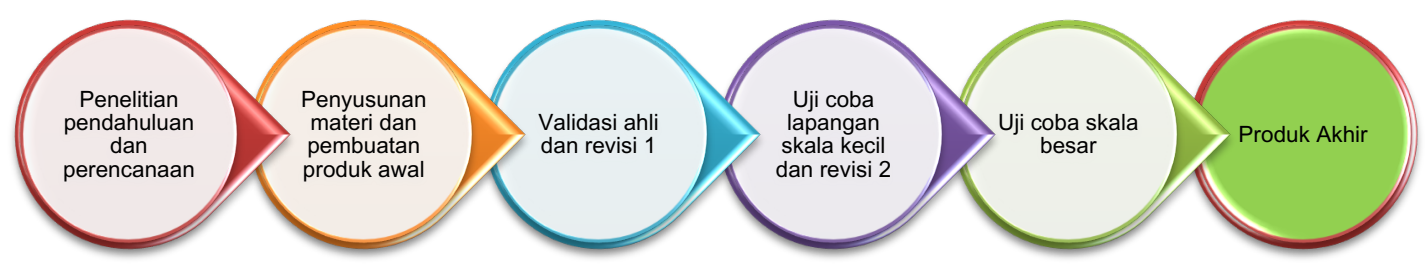

\section{Gambar 1. Tahap-Tahap Penelitian}

Pertama, analisis produk digunakan. Kegiatan ini bertujuan untuk mengetahui spesifikasi produk yang diperlukan berupa media atau bahan ajar mata pelajaran Bahasa Indonesia yang mengintegrasikan ekoliterasi. Kedua, pembuatan produk awal. Kegiatan ini meliputi telaah materi, metode pembelajaran, pengembangan indikator, pemilihan platform yang akan digunakan, serta penyusunan materi yang sesuai berdasarkan analisis kebutuhan. Ketiga, validasi. Kegiatan ini dilakukan dengan melibatkan tiga ahli, yaitu ahli materi, media, dan bahasa dengan kualifikasi ahli di bidang materi, media, dan bahasa, serta memiliki minimal jenjang pendidikan S2. Keempat, uji coba skala kecil. Kegiatan ini meliputi uji coba skala kecil yang melibatkan praktisi dan 12 siswa kelas 9 serta revisi tahap 2. Kelima, uji coba skala 
besar. Kegiatan ini meliputi uji coba skala besar yang melibatkan 56 siswa kelas 9 . Melalui kelima tahap tersebut, diperoleh produk akhir. Produk ini adalah modul elektronik menulis teks tanggapan berbasis learning management system Moodle dengan muatan ekoliterasi untuk kelas 9.

\section{PEMBAHASAN}

Berikut ini adalah pembahasan data penelitian dan pembahasan hasil berupa modul elektronik menulis teks tanggapan berbasis ekoliterasi.

\section{Analisis Data}

Paparan analisis data meliputi hasil validasi ahli, uji praktisi dan uji coba lapangan skala kecil, serta uji coba skala besar. Berikut ini adalah paparan hasil uji coba.

\section{a. Validasi Ahli}

Validasi ahli dilakukan untuk menguji kelayakan produk berdasarkan kriteriakriteria tertentu yang sesuai. Modul elektronik yang dikembangkan telah melalui tahap validasi ahli materi, validasi ahli media, dan validasi ahli bahasa. Ahli materi memberikan skor sebesar 87,5\%, ahli media memberikan skor sebesar 92,5\%, dan ahli bahasa memberikan skor sebesar 70,5\%. Hasil validasi menyatakan bahwa produk yang dikembangkan layak untuk diujicobakan dengan beberapa revisi.

Tabel 1. Hasil Validasi Ahli

\begin{tabular}{ccc}
\hline Validator & Skor & Kriteria \\
\hline Materi & $87,5 \%$ & Layak digunakan \\
Media & $92,5 \%$ & Layak digunakan \\
Bahasa & $70,5 \%$ & Layak digunakan \\
\hline
\end{tabular}

\section{b. Uji Lapangan Skala Kecil}

Uji lapangan skala kecil dilakukan dengan melibatkan 12 siswa kelas 9. Uji coba ini dilakukan sebelum pengujian produk dalam skala besar dan bertujuan untuk menilai penggunaan produk sebelum diaplikasikan secara luas. Hasil uji coba skala kecil memperoleh skor sebesar $75 \%$ dengan beberapa saran revisi. Saran tersebut digunakan untuk perbaikan produk.

\section{c. Uji Lapangan Skala Besar}

Uji coba skala besar dilakukan dengan melibatkan 56 siswa kelas 9. Uji coba ini bertujuan untuk menilai aplikasi produk secara luas. Hasil uji coba lapangan skala besar mendapatkan skor $85,7 \%$ dan dinyatakan layak digunakan dalam pembelajaran.

\section{Analisis Produk}

Penelitian ini menghasilkan modul elektronik berbasis platform Moodle yang dapat diakses secara daring maupun luring serta memuat ekoliterasi untuk kelas 9 SMP. Pengembangan modul didasarkan pada fungsinya yang digunakan sebagai pelengkap buku teks utama yang digunakan di sekolah, yaitu buku teks Bahasa Indonesia untuk Kelas IX terbitan Kementerian Pendidikan dan Kebudayaan. Berikut ini adalah pembahasan produk modul elektronik menulis teks tanggapan berbasis ekoliterasi untuk kelas IX yang meliputi konten dan sajian. 


\section{a. Konten Modul Elektronik Bermuatan Ekoliterasi}

Konten bermuatan ekoliterasi terdapat dalam bagian pendahuluan, isi bab, bagian evaluasi, dan penyudah bab. Secara lebih spesifik muatan ekoliterasi terdapat dalam judul bab, topik dalam setiap bab, model teks, latihan, dan sajian contoh kasus yang harus ditanggapi siswa. Konten ekoliterasi bukan berarti hanya terdiri dari berbagai permasalahan tentang lingkungan hidup, namun juga upaya penyelesaiannya. Mercer (2021) menyatakan bahwa nilai yang terkandung dalam konten ekoliterasi ini berguna sebagai dasar membangun masyarakat yang sejahtera selaras dengan kesejahteraan lingkungan. Konten ekoliterasi terdapat dalam pelajaran struktur teks tanggapan, pelajaran kebahasaan teks tanggapan, dan pelajaran menulis teks tanggapan.

Pada bagian struktur teks tanggapan, topik utama yang dimuat adalah tentang masalah dan pelestarian hutan. Hutan merupakan sebuah tempat yang kaya akan sumber daya alam sarat manfaat bagi manusia (Matnuril et al., 2019). Oleh sebab itu, hutan juga menjadi salah satu objek pelestarian lingkungan. Indikator seseorang yang dapat menerapkan ekoliterasi dapat diketahui dari kecintaannya terhadap hutan dan berupaya melestarikannya. Seseorang yang ekoliterat juga paham betul pentingnya kedudukan hutan dalam kelangsungan hidup makhluk lain (Rahmawati, 2017). Dalam bagian struktur teks memuat prinsip ekologi berupa jejaring, kemitraan, keanekaragaman, dan keseimbangan dinamis. Muatan prinsip jejaring dan kemitraan terdapat pada pelajaran 1 halaman 6.

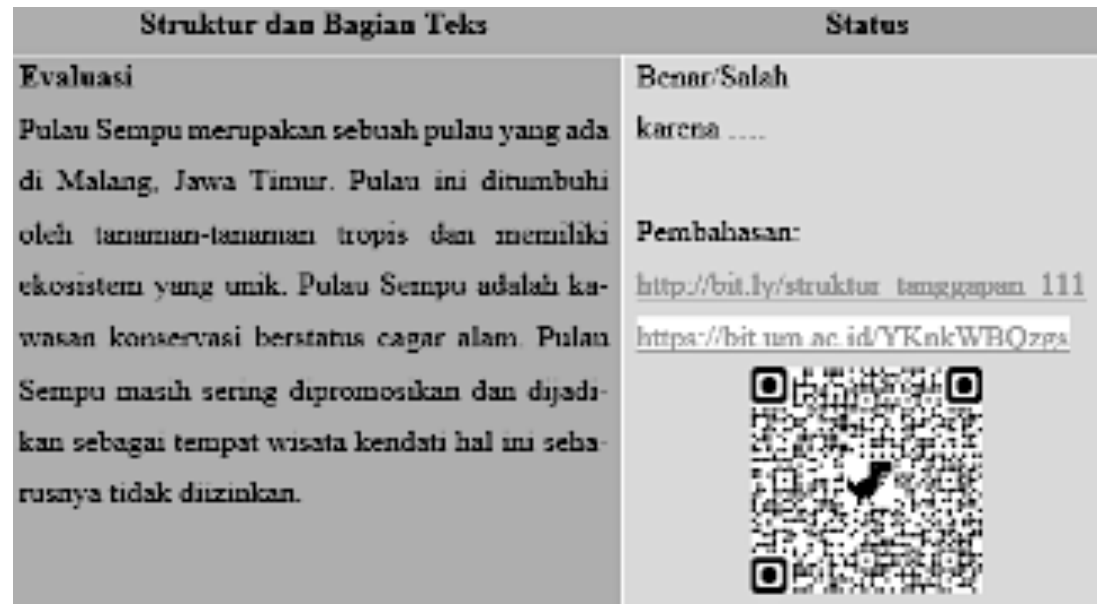

\section{Gambar 2. Ekoliterasi dalam Pelajaran Struktur Teks Tanggapan}

Terdapat prinsip keanekaragaman berupa melimpahnya keanekaragaman hayati di Pulau Sempu yang terkandung pada bagian evaluasi yang menerangkan Pulau Sempu secara singkat. Penerapan prinsip keseimbangan dinamis dan kemitraan ditunjukkan oleh upaya lembaga terkait menciptakan ekosistem Pulau Sempu supaya tetap terjaga. Menurut Ihsan \& Hanami (2021) indikasi keseimbangan dinamis terdapat pada bertahannya ekosistem tersebut sehingga dapat melindungi dirinya sendiri dari ancaman-ancaman, termasuk ancaman perusakan yang dilakukan oleh manusia. Bagian yang mengandung prinsip ekoliterasi ini terdapat pada struktur teks tanggapan berupa penegasan ulang. Keseimbangan dinamis yang terdapat dalam konten ini adalah tetap bertahannya ekosistem Pulau Sempu karena upaya pelestarian yang dilakukan oleh lembaga terkait. Namun, jika pelanggaran 
prinsip yang lain masih dilakukan secara berulang mungkin juga keseimbangan yang ada akan goyah dan membentuk sistem keseimbangan baru.

Konten lainnya adalah teks yang menunjukkan perilaku konsumtif terhadap fesyen dan dampaknya terhadap kehidupan. Konten ini memuat penyimpangan terhadap prinsip ekologi. Pemakaian produk fesyen yang berlebihan dapat merusak lingkungan karena berbagai faktor di antaranya pemakaian bahan sintetis, pemakaian bagian tubuh hewan, pemborosan air, polusi, peningkatan emisi gas rumah kaca, serta risiko limbah pakaian (Indraswari, 2021). Tren fesyen yang cepat dan berlebihan juga mengajarkan kebiasaan buruk berupa boros dan tidak mempertimbangkan anggaran belanja secara matang, hal ini tentunya sangat berlawanan dengan prinsip kehidupan berkelanjutan. Namun, penyimpangan yang terdapat dalam contoh dimaksudkan supaya siswa lebih memahami aktivitas seharihari mereka yang dapat menyebabkan perubahan iklim. Dengan konten ini siswa juga dapat menjadi lebih peka terhadap masalah lingkungan yang sedang berlangsung dan jika dibiarkan dapat mengancam kelangsungan hidup mereka.

Konten ekoliterasi dalam teks tanggapan selanjutnya terdapat dalam pelajaran kebahasaan teks tanggapan. Ciri kebahasaan pada teks tanggapan terdiri dari penggunaan gaya bahasa yang santun, penggunaan opini, penggunaan kalimat deskripsi, dan penggunaan argumen untuk menguatkan atau melemahkan pendapat. Muatan ekoliterasi pada bagian kebahasaan teks tanggapan terdapat dalam topik pelajaran tentang sampah dan penanganannya. Prinsip ekologi pada bagian ini adalah jejaring, siklus, energi surya, kemitraan, dan keseimbangan dinamis. Sampah merupakan sumber masalah yang harus segera ditangani supaya tidak semakin mencemari lingkungan. Oleh sebab itu, pada bagian ini selain mempelajari kebahasaan teks tanggapan siswa juga mengetahui dan dapat memikirkan cara menanggulangi masalah sampah.

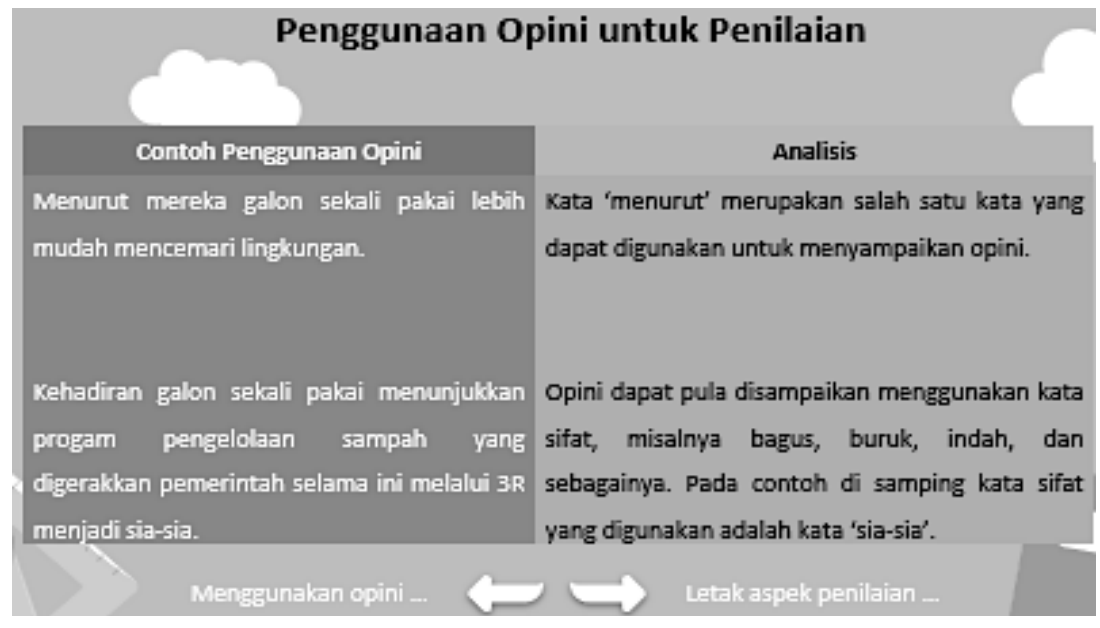

\section{Gambar 3. Ekoliterasi dalam Pelajaran Kebahasaan Teks Tanggapan}

Pada ciri kebahasaan teks tanggapan berupa penggunaan gaya bahasa yang santun, muatan ekoliterasi yang ada berupa jejaring, kemitraan, dan keseimbangan dinamis. Pada bagian ciri kebahasaan ini ditampilkan teks tentang penolakan penggunaan galon sekali pakai dan konsekuensi pencemaran yang tetap ada meski galon sekali pakai tersebut didaur ulang. Kendati hal yang disampaikan adalah 
ketidaksetujuan yang disertai argumen yang masuk akal, penulis tetap menggunakan bahasa yang sopan untuk menyampaikan bahaya penggunaan galon sekali pakai.

Pada ciri kebahasaan teks tanggapan berupa penyampaian opini, muatan ekoliterasi yang ada berupa jejaring, kemitraan, dan keseimbangan dinamis. Konten tersebut adalah tampilan bagian ciri kebahasaan yang menampilkan pendapat bahwa pemakaian galon sekali pakai lebih mudah mencemari lingkungan. Prinsip kemitraan yang terdapat pada bagian ini bukanlah sebuah penerapan, melainkan pelanggaran karena tidak terjadinya kesepakatan untuk menggunakan produk yang lebih tidak mencemari lingkungan dan juga tidak terdapat kesepakatan pengelolaan limbah dari penggunaan galon sekali pakai. Prinsip keseimbangan dinamis yang terdapat pada bagian ini berupa pelanggaran terhadap praktiknya karena terdapat elemen yang tidak sejalan untuk pelaksanaan program $3 \mathrm{R}$ yang harusnya dilakukan secara berurutan mulai dari recuce, reuse, dan recycle.

Pada ciri kebahasaan teks tanggapan berupa penggunaan kalimat deskripsi prinsip ekologi yang diterapkan adalah jejaring dan keseimbangan dinamis. Pada bagian ini memuat langkah-langkah memelihara lingkungan dengan cara penanganan sampah. Setelah sampah dapat ditangani lebih baik, dampaknya akan terasa pada masyarakat tersebut. Dengan penanganan sampah, maka akan menumbuhkan sikap peduli, disiplin, kreatif, dan lebih menghayati anugerah berupa alam yang indah dan lestari (Wardaniah et al., 2019).

Pada ciri kebahasaan teks tanggapan berupa terdapatnya argumentasi atau kalimat argumen muatan ekoliterasi berupa jejaring dan keseimbangan dinamis. Argumentasi yang digunakan adalah kehadiran sampah plastik yang lebih mencemari lingkungan dan bahaya lain jika daur ulang tidak diterapkan, serta pelanggaran terhadap prinsip penanganan sampah 3R. Dengan mengizinkan penggunaan galon sekali pakai, maka konsekuensi bahayanya terhadap lingkungan dan kesehatan manusia akan semakin tampak. Argumen ini menunjukkan sikap ekoliterat dari penulis yang menunjukkan ketidaksetujuannya terhadap pemakaian galon sekali pakai yang berpotensi lebih mencemari lingkungan dibandingkan galon isi ulang.

Muatan ekoliterasi yang terdapat pada latihan ciri kebahasaan teks tanggapan berupa jejaring, siklus, energi surya, kemitraan, keanekaragaman, dan keseimbangan dinamis. Jejaring terdapat dalam latihan 1a. yaitu pengaruh tayangan anak terhadap perkembangan intelektualnya yang secara tidak langsung membentuk kemampuan literasinya, termasuk ekoliterasi. Jika tayangan tersebut mengandung pengetahuan tentang cara mengatasi masalah lingkungan, maka tayangan juga dapat mengedukasi dan menumbuhkan ekoliterasi anak.

Prinsip keanekaragaman terdapat dalam latihan $1 \mathrm{~b}$ yang memuat pengetahuan tentang dampak pemanasan bumi yang dapat menurunkan keanekaragaman hayati. Prinsip keanekaragaman ini memiliki hubungan dengan prinsip jejaring dan keseimbangan dinamis, yaitu organisme saling berhubungan dan ekosistem menciptakan keseimbangan sebagai tempat tinggal bagi organisme-organisme tersebut. Menurut Ihsan \& Hanami (2021) keseimbangan dinamis dapat ditandai dengan adanya keanekaragaman, semakin beragam variasi organisme dalam suatu ekosistem, maka ekosistem tersebut semakin stabil.

Prinsip kemitraan termuat dalam latihan 1c, yaitu kemitraan untuk meningkatkan kesejahteraan petani melalui sistem tanam mina padi. Bagian ini menunjukkan bahwa memelihara lingkungan sangatlah penting karena lingkungan 
dimanfaatkan manusia untuk bertahan hidup, oleh sebab itu manusia harus merawatnya. Prinsip jejaring, siklus, kemitraan, dan keseimbangan dinamis juga terdapat dalam latihan 1g, yaitu kontribusi seni terhadap upaya pelestarian lingkungan. Seni dibuat dengan memanfaatkan bahan alam dan ada pula yang memanfaatkan limbah. Prinsip siklus yang terjadi adalah proses daur ulang atau pemanfaatan kembali limbah menjadi barang bernilai guna dan bernilai ekonomis, sehingga menjadi alternatif pengolahan sampah. Kemitraan yang terjadi adalah kerja sama antar para seniman dan lembaga terkait untuk menangani masalah lingkungan berupa sampah. Dengan pemanfaatan ini telah dilakukan ekoliterasi karena pengetahuan dan sumber daya dimanfaatkan untuk menumbuhkan kreativitas dalam pengelolaan lingkungan.

Penerapan ekoliterasi oleh masyarakat yang ekoliterat dinampakkan dalam latihan $1 \mathrm{j}$, yaitu pengembangan sebuah sistem pembelajaran yang menerapkan sustainable living. Penerapan pembelajaran yang berorientasi pada pendidikan lingkungan hidup hampir dilaksanakan pada semua lini, yaitu pengintegrasian muatan pendidikan lingkungan hidup, pembiasaan siswa, dan praktik pembelajaran (Rusmana \& Aulia, 2017). Pengetahuan tentang sekolah berbasis lingkungan hidup yang mampu diterapkan pada sekolah biasa diharapkan dapat mendorong dan menginspirasi untuk memulai sistem sekolah yang serupa.

Konten ekoliterasi selanjutnya terdapat dalam pembelajaran menulis teks tanggapan. Kompetensi yang diharapkan untuk dikuasai siswa pada pembelajaran menulis teks tanggapan adalah mereka mampu mengungkapkan kritik, sanggahan, atau pujian dengan memperhatikan struktur dan kebahasaan (Alatas, 2018). Kompetensi tersebut tidaklah mudah dikuasai oleh siswa secara langsung. Siswa haruslah mengetahui dan memiliki kompetensi dalam struktur dan kebahasaan teks tanggapan, siswa juga harus mampu merangkai kata untuk dapat mengungkapkan gagasan yang tepat (Ningsih \& Firmansyah, 2020). Oleh sebab itu, modul elektronik ini diperkaya latihan menulis teks tanggapan yang variatif.

Cara yang dilakukan supaya siswa lebih mahir mengungkapkan gagasannya dalam menanggapi sesuatu adalah menuntun mereka untuk lebih peka terhadap lingkungan di sekitar mereka. Misalnya saja menyajikan masalah tentang lingkungan sekitar untuk ditanggapi oleh siswa. Dengan demikian, latihan yang disajikan juga menuntun kepada pengembangan kreativitas mereka dalam memecahkan masalah di lingkungan sekitar. Jika hal tersebut terlaksana, maka siswa selangkah lebih dekat untuk menjadi pribadi yang ekoliterat.

Prinsip ekologi yang terdapat dalam pelajaran menulis teks tanggapan adalah jejaring, siklus, energi surya, kemitraan, dan keseimbangan dinamis. Prinsip jejaring yang terdapat dalam bagian ini adalah kesadaran adanya hubungan yang erat antara perilaku satu organisme dengan organisme yang lain sehingga mempengaruhi hubungan dan interaksi keduanya. Kesadaran adanya hubungan erat ini berimplikasi terhadap tindakan yang diambil oleh sejumlah pelaku industri untuk ikut serta dalam pelestarian lingkungan (Yunansah \& Herlambang, 2017). Hal ini terdapat pada bagian berupa teks yang berjudul Perusahaan Dunia Mendukung Kelestarian Lingkungan Hidup.

Dalam teks dengan judul yang sama juga terdapat prinsip ekologi berupa siklus, kemitraan, dan keseimbangan dinamis. Prinsip siklus dalam konten pembelajaran 3 ini adalah kegiatan pengolahan ulang atau daur ulang sampah. Prinsip energi surya terdapat dalam konten yang mengandung informasi bahwa energi surya digunakan 
sebagai bahan bakar industri sehingga lebih ramah lingkungan. Prinsip kemitraan yang terjalin berupa kerja sama pengelolaan limbah dan inovasi sistem kerja industri sehingga tidak menghasilkan banyak emisi. Prinsip keseimbangan dinamis terdapat pada upaya perusahaan untuk berinovasi mengolah limbah plastik sehingga mengurangi pencemaran lingkungan. Upaya ini tentunya baik untuk menjaga keseimbangan lingkungan.

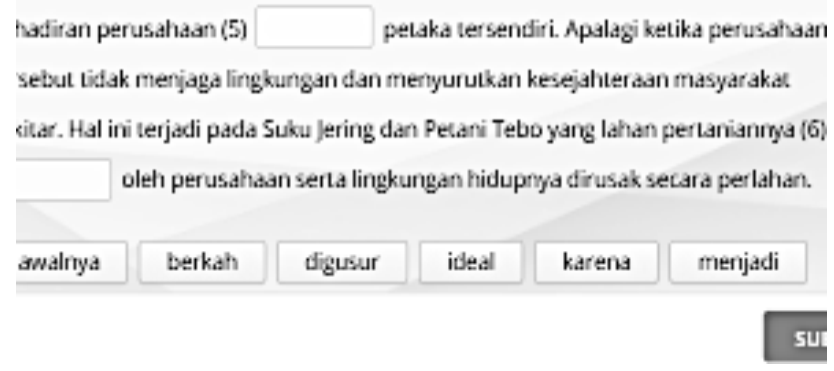

\section{Gambar 4. Latihan Menulis Teks Tanggapan Bermuatan Ekoliterasi}

Konten yang menunjukkan ekoliterasi atau penerapan prinsip ekologi terdapat dalam bahan menulis teks tanggapan menggunakan metode menulis terbimbing. Topik yang diintegrasikan memiliki kesinambungan terhadap upaya-upaya pelestarian lingkungan hidup dan tindakan yang menunjukkan sikap ekoliterat. Konten tersebut adalah larangan membuang sampah di sungai dengan konsekuensi berupa denda dan hukuman. Konten lainnya berkenaan dengan industri berkelanjutan dan penggunaan energi alternatif ramah lingkungan, serta pengelolaan sumber daya air. Adapun konten yang berisi pemanfaatan sampah organik yang diolah menjadi bahan pakan ternak.

\section{b. Penyajian Modul Elektronik}

Penyajian multimedia terdiri dari beberapa komponen, yaitu teks, gambar, suara, video, dan media interaktif (Surjono, 2017). Komponen-komponen tersebut tidak harus ada semua, namun saling terpadu dan melengkapi. Teknik penyajian modul disusun berdasarkan ragam media yang digunakan dan standar kelayakan pengembangan multimedia. Standar kelayakan multimedia menurut Wahono (2006) meliputi kesesuaian materi dengan tujuan pembelajaran, ketepatan materi dan urutan penyajiannya, kemutakhiran perangkat lunak atau aplikasi yang digunakan, kemudahan petunjuk operasional, kejelasan aspek visual, audio, dan audiovisual, relevansi latihan dengan indikator ketercapaian kompetensi, dan umpan balik. Penyajian media haruslah jelas, mudah dipahami, dan komunikatif.

Komponen multimedia berupa teks dalam modul digunakan dalam petunjuk penggunaan, penyampaian tujuan pembelajaran, materi dan teks model, latihan, serta evaluasi. Menurut (Surjono, 2017) secara umum, tujuan dari keberadaan teks adalah sarana penyampaian informasi dalam bentuk tulisan supaya lebih mudah dimengerti oleh pengguna. Sajian teks mengharuskan penggunaan huruf dengan jenis dan ukuran yang sesuai dan konsisten. Penggunaan huruf dalam modul elektronik adalah jenis Patrick Hands dengan ukuran 22 point untuk judul, dan 14 point untuk ukuran teks biasa. Muatan ekoliterasi jelas terdapat dalam sajian teks karena konten utama dalam modul elektronik adalah ekoliterasi. Prinsip ekologi 
yang terdapat dalam sajian teks meliputi jejaring, siklus, energi surya, kemitraan, keanekaragaman, dan keseimbangan dinamis.

Konten utama modul elektronik yang mengandung ekoliterasi jelas mengindikasikan keberadaan ekoliterasi. Materi dan teks model yang disajikan dalam modul memuat prinsip-prinsip ekologi, baik yang merupakan penerapan prinsip tersebut maupun pelarangannya. Bagian tujuan pembelajaran juga memuat nilai-nilai dan mengandung indikator ketercapaian pembelajaran berupa kecakapan yang ditunjukkan ketika seseorang menjadi ekoliterat, misalnya mengetahui dan memahami prinsip ekologi, peka terhadap masalah lingkungan dan menemukan solusi mengatasinya, serta menulis tanggapan terhadap hal-hal yang berkenaan dengan lingkungan hidup.

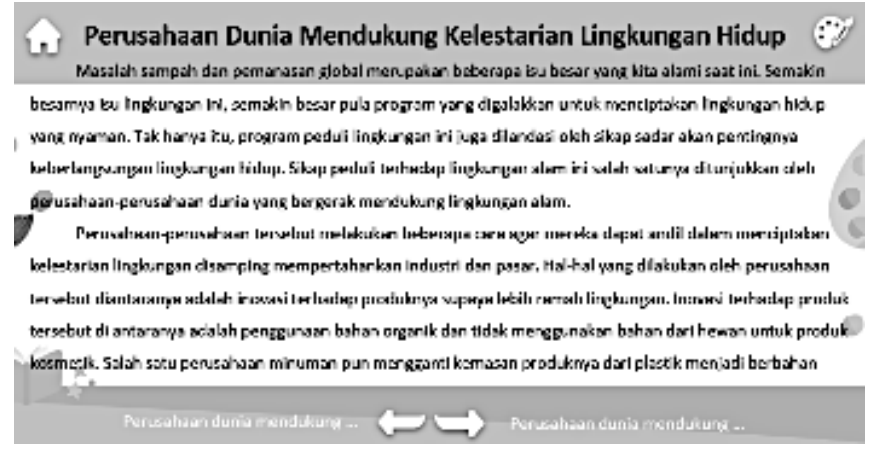

\section{Gambar 5. Sajian teks ekoliterasi}

Penggunaan gambar bertujuan untuk mengilustrasikan secara visual sebuah informasi (Surjono, 2017). Tujuan keberadaan gambar adalah memudahkan penyampaian informasi verbal yang dirasa masih abstrak. Pemilihan gambar mempertimbangkan kesesuaiannya dengan pesan yang ingin disampaikan, resolusi atau tingkat ketajaman gambar, dan warna yang digunakan gambar. Fungsi gambar dalam modul elektronik adalah memberikan gambaran terkait benda atau fenomena yang berhubungan dengan konten ekoliterasi.

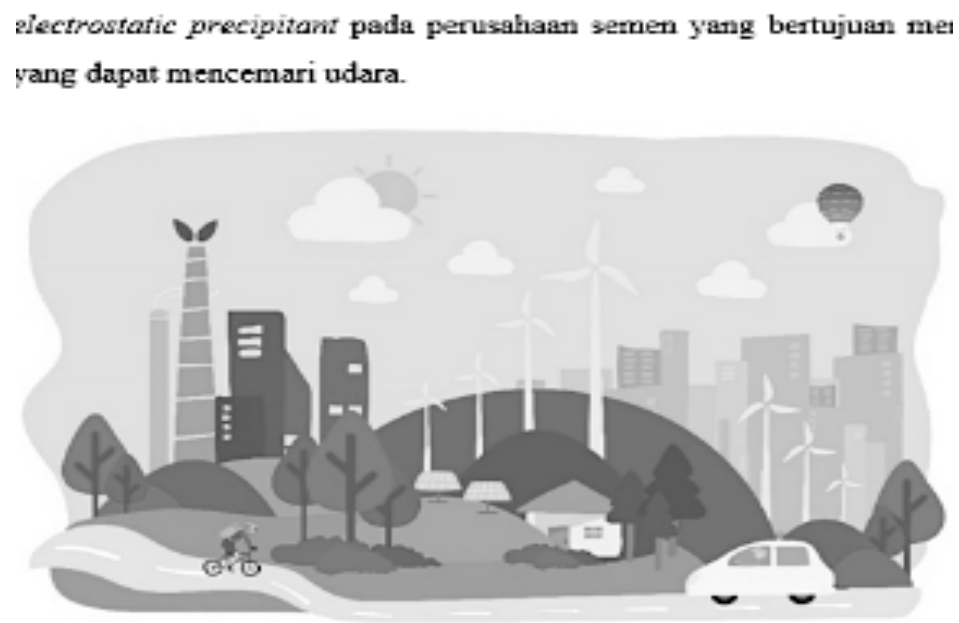

Gambar 6. Sajian gambar masyarakat ekoliterat 
Sajian gambar bermuatan ekoliterasi yang terdapat dalam modul elektronik di antaranya adalah gambar panel surya, gambar produk olahan sampah, Interceptor 001, dan ilustrasi masyarakat berkelanjutan. Gambar-gambar ini menunjukkan penerapan ekoliterasi berupa ajakan untuk bersama-sama menjadi bagian dalam membangun masyarakat berkelanjutan. Gambar yang ditayangkan dibuat menginspirasi supaya siswa atau mengguna merasa jika dirinya adalah salah satu pemeran penting dalam upaya pelestarian lingkungan ke arah yang lebih baik. Salah satu contohnya adalah gambar yang menunjukkan kemampuan ekoliterasi masyarakat yang peduli dengan lingkungan sungai. Dalam gambar tersebut diilustrasikan dengan gambar papan peringatan yang berisi denda dan hukuman bagi pelaku pembuangan sampah di sungai.

Komponen multimedia berupa audio berfungsi untuk menyampaikan informasi dalam bentuk suara kepada pengguna (Indriastuti, 2014, p. 94). Fungsi audio dalam modul elektronik seperti seharusnya, yaitu menyampaikan informasi berupa narasi teks dan petunjuk pengerjaan latihan untuk siswa. Bahasa yang digunakan dalam audio adalah bahasa Indonesia baku dengan intonasi yang sesuai dan tempo pengucapan yang sedang. Audio digunakan untuk mempermudah siswa yang lebih suka mendengarkan daripada membaca. Pengoperasian audio dalam modul elektronik dapat disesuaikan oleh siswa yang berarti dapat dihidupkan atau dimatikan apabila siswa tidak mau menggunakannya.

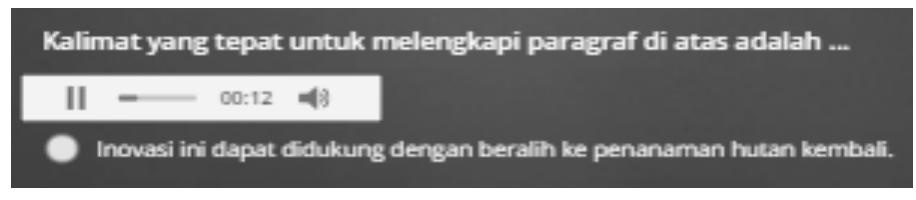

\section{Gambar 7. Sajian Audio}

Muatan ekoliterasi dalam audio terdapat dalam isi yang disampaikan di dalamnya. Isi atau informasi yang disampaikan melalui media audio berhubungan dengan konten modul elektronik yang memang memiliki nilai-nilai yang mengandung prinsip ekologi, di antaranya adalah audio yang menginformasikan tentang tanggapan mengenai gaya hidup sehat dan ramah lingkungan yang diterapkan di sekolah. Nilai-nilai ekoliterasi lainnya yang disampaikan melalui modul elektronik adalah nilai hemat energi, cerdas dan bijak memanfaatkan dan mengelola lingkungan, nilai-nilai menjaga dan melestarikan lingkungan, dan nilainilai inovasi untuk menciptakan ekosistem tinggal yang lebih baik.

Komponen multimedia berupa video dalam modul elektronik berfungsi sebagai penunjang materi yang telah disajikan (Surjono, 2017). Sajian video memuat nilainilai ekoliterasi berupa pemanfaatan sampah dan pengelolaan energi dan sumber daya air. Muatan video yang mengandung masalah ekoliterasi adalah pemanfaatan hutan secara tidak bijak serta kendala dihadapi untuk mewujudkan masyarakat berkelanjutan berupa emisi gas dan konsumsi energi fosil yang menyebabkan perubahan iklim. 


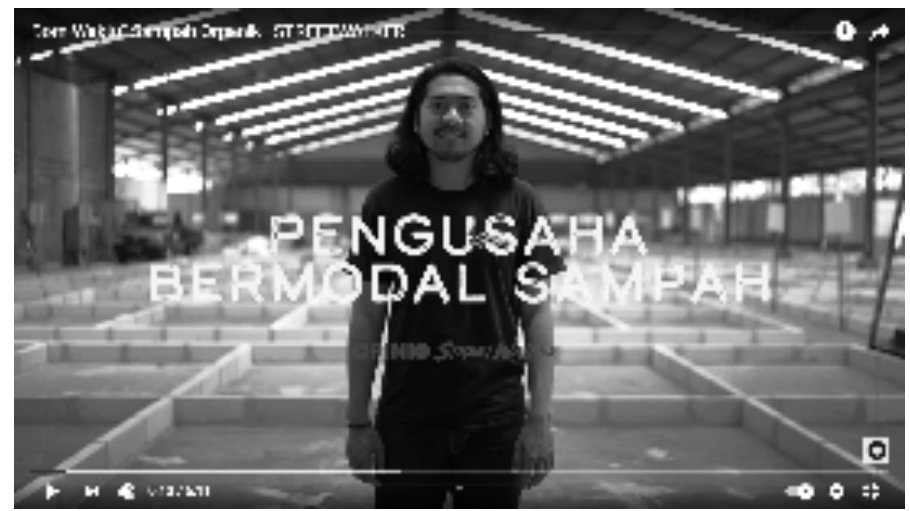

\section{Gambar 8. Sajian Video}

Pemanfaatan hutan secara tidak bijak dapat menimbulkan bencana alam (Matnuril et al., 2019). Seperti yang kita tahu bahwa hutan memiliki peran yang vital dalam kehidupan manusia. Dalam video dijelaskan alasan manusia memerlukan hutan dan cara mereka memperlakukan hutan dengan tidak ramah. Wujud dari ketidakramahan itu adalah penebangan kayu hutan yang tidak diiringi oleh penanaman kembali, akibat yang mungkin terjadi adalah longsor, banjir, erosi, terbawanya tanah humus yang subur oleh aliran air hujan, serta kurangnya resapan air yang dapat menimbulkan kekeringan di kemudian hari.

\section{PENUTUP}

Penelitian ini menghasilkan modul elektronik menulis teks tanggapan bermuatan ekoliterasi yang dapat diakses secara daring maupun luring. Modul ini digunakan untuk membantu pembelajaran menulis teks tanggapan yang dilaksanakan secara daring pada era pandemi. Modul memiliki kelayakan dari segi konten, penyajian, dan kebahasaan. Konten modul bermuatan ekoliterasi terdapat dalam pemilihan topik, judul bab, materi, latihan, evaluasi, dan kasus yang harus ditanggapi oleh siswa yang mengintegrasikan pengetahuan dan permasalahan tentang lingkungan hidup beserta solusinya. Modul ini disajikan menggunakan multimedia yang mengandung unsur ekoliterasi yang meliputi teks, gambar, audio, dan video.

\section{UCAPAN TERIMA KASIH}

Terima kasih kepada Universitas Negeri Malang karena telah mendanai penelitian ini melalui PNBP UM tahun anggaran 2021 dengan nomor kontrak 4.3.13/UN32/KP/2021.

\section{DAFTAR PUSTAKA}

Alatas, M. A. (2018). Penalaran dalam Paragraf Teks Tanggapan Kritis Siswa Kelas IX SMP Negeri 3 Malang [Universitas Negeri Malang]. http://karyailmiah.um.ac.id/index.php/disertasi/article/view/66620

Artani, A. (2020). Pengaruh Pendekatan Chemo-Enterpreneurship (CEP) pada Model Pembelajaran Inkuiri Terbimbing Berbantuan Kahoot Terhadap Hasil Belajar Kognitif dan Afektif Peserta Didik [Universitas Negeri Semarang]. 
http://lib.unnes.ac.id/42876/1/4301416086.pdf

Banki, S. R. (2021). Learning Alone with Corona: Two Challenges and Four Principles of Tertiary Teaching. Journal of Research in Innovative Teaching \& Learning, 14(1), 65-74. https://doi.org/10.1108/jrit-12-2020-0081

Ihsan, A. F., \& Hanami, Z. A. (2021). Implementasi Ekoliterasi di Era Pascaliterasi. Prosiding Seminar Nasional Adiwidya 8 Pascasarjana ITB, January, 42-47. https://www.researchgate.net/publication/348522744_Implementasi_Ekoliter asi_di_Era_Pascaliterasi

Indraswari, D. L. (2021, April 16). Ancaman Kerusakan Lingkungan dari Industri "Fast Fashion." Kompas. https://interaktif.kompas.id/baca/ancamankerusakan-lingkungan-dari-industri-fast-fashion/

Indriastuti, F. (2014). Peran Media Audio dalam Implementasi Kurikulum 2013 Melalui Pembelajaran Tema Terpadu di Sekolah Dasar. Kwangsan, 2(2), 92107. https://core.ac.uk/download/pdf/235523122.pdf

Long, T. M., Dauer, J. T., Kostelnik, K. M., Momsen, J. L., Wyse, S. A., Speth, E. B., \& Ebert-May, D. (2014). Fostering Ecoliteracy Through Modelbased Instruction. Frontiers in Ecology and the Environment, 12(1), 138-139. https://www.jstor.org/stable/43187728?Search=yes\&resultItemClick=true\&s earchText=ECOLITERACY\&searchUri $=\% 2$ Faction $\% 2$ FdoBasicSearch $\% 3 \mathrm{FQ}$ uery\%3DECOLITERACY\%26acc\%3Doff\%26wc\%3Don $\% 26 \mathrm{fc} \% 3$ Doff $\% 26$ gro up\%3Dnone\%26refreqid\%3Dsearch\%253A14e36e8463a0d7a739ea83412af21c 38

Mairina, V., Firman, \& Desyandri. (2021). Peningkatan Hasil Belajar Siswa dalam Pembelajaran Ilmu Pengetahuan Alam dengan Pendekatan Keterampilan Proses di Sekolah Dasar. JRTI: Jurnal Riset Tindakan Indonesia, 6(1), 34-39.

Matnuril, Jeddawi, M., Kusworo, \& Supriyadi, B. (2019). Implementasi Kebijakan Pengelolaan Kawasan Konservasi Taman Nasional Tesso Nilo dalam Menjaga Kelestarian Fungsi Hutan Kabupaten Pelalawan, Provinsi Riau, Indonesia. Media Bina Ilmiah, 13(11), 1793-1812. http://ejurnal.binawakya.or.id/index.php/MBI/article/view/377/pdf

Mercer, S. (2021). An Agenda for Well-Being in ELT: An Ecological Perspective. ELT Journal, 75(1), 14-21. https://doi.org/10.1093/elt/ccaa062

Ningsih, D. N., \& Firmansyah, A. (2020). Pemanfaatan Virtual Reality pada Pembelajaran Menulis Teks Tanggapan. Prosiding SAMASTA Seminar Nasional Bahasa Dan Sastra Indonesia. https://jurnal.umj.ac.id/index.php/SAMASTA/article/view/7144

Rahmawati, F. P. (2017). Kepedulian Lingkungan dalam "Nusantara Bertutur": Bentuk Penguatan Karakter dan Ekoliterasi melalui Sastra Anak. The 1st International Conference on Language, Literature and Teaching, 546-556. https://publikasiilmiah.ums.ac.id/bitstream/handle/11617/8908/i9.pdf?sequ ence $=1 \&$ isAllowed $=y$

Rigolon, A. (2012). A Greener Future: The Active Role of Place in Enhancing Ecoliteracy Children. Journal of Architectural and Planning Research, 29(3), 181203. https://bit.ly/3gckId8

Rusmana, N. E., \& Aulia, A. (2017). Pembelajaran Ekoliterasi Berbasis Proyek di Sekolah Dasar. JESA Jurnal Edukasi Sebelas April, 1(1), 33-44. https://ejournal.stkip11april.ac.id/index.php/jesa/article/view/62/49

Semetsky, I. (2010). Ecoliteracy and Dewey's Educational Philosophy: Implication 
for Future Leaders. Foresight, 12(1), 31-44. https://bit.ly/34UQPZL

Setyaningrum, T. W., \& Gunansyah, G. (2020). Praktik Pembelajaran Ekoliterasi

Berorientasi Pendidikan untuk Pembangunan Berkelanjutan di Sekolah Dasar

Negeri Kota Surabaya Bagian Barat. Jurnal Penelitian Pendidikan Guru Sekolah Dasar, 8(2), 375-384. https://bit.ly/35jit2J

Sulaiman, L. (2020). Pengaruh Metode Pembelajaran dan Berpikir Kritis Terhadap Kemampuan Menulis Argumentasi. Teacher, 1(1). https://bit.ly/3vkV8rK

Surjono, H. D. (2017). Multimedia Pembelajaran Interaktif. In UNY Press. UNY Press.

Syukron, A. (2018). Pengembangan Bahan Ajar Menulis Teks Laporan Hasil Observasi Bertema Green Industry sebagai Pembentuk Scientific Awareness. http://pbsi.fkip.unej.ac.id/wp-content/uploads/sites/12/2018/04/AHMADSYUKRON-FKIP-PRESENTASI-POSTER-PDP-2018-ukuran-70x100.jpg

Wardaniah, D., Lestari, I. D., \& Ramdhayani, E. (2019). Ekoliterasi Siswa Melalui Kegiatan Pengelolaan Sampah Berbasis Group Investigation di SMAN 1 Moyo Utara Tahun Pelajaran 2017/2018. Klasikal: Journal of Education, Language Teaching and Science, 32-37. https://core.ac.uk/download/pdf/270203886.pdf

Wulandari, R., Susilo, H., \& Kuswandi, D. (2017). Penggunaan Multimedia Interaktif Bermuatan Game Edukasi untuk Siswa Sekolah Dasar. Jurnal Pendidikan: Teori , Penelitian Dan Pengembangan, 2(8), 1024-1029. http://journal.um.ac.id/index.php/jptpp/article/view/9759/4611

Yunansah, H., \& Herlambang, Y. T. (2017). Ecopedagogic Based Education in Raising Ecological Awareness and Developing Character in Elementary School Students. EduHumaniora | Jurnal Pendidikan Dasar Kampus Cibiru, 9(1), 27.

Yuniawan, T. (2017). Membangun Rumah Ilmu Berekoliterasi Konservasi. UNNES. https://unnes.ac.id/gagasan/membangun-rumah-ekoliterasi-konservasiuntuk-menjaga-dan-merawat-bumi 